\title{
RELIABILITA BATÉRIE METÓD NA VYHODNOTENIE KOGNITÍVNEHO DEFICITU, DEPRESIE A FUNKČNÉHO STAVU PACIENTOV $S$ DEMENCIOU
}

\author{
ŠTEFAN ANDERKO 1
}

\begin{abstract}
Abstrakt: V klinickom výskume sme vzorke pacientov $(N=67)$ z Domova pro seniory Nopova administrovali viaceré psychodiagnostické metódy s ciel'om overit' ich reliabilitu pri širšom popise demencie. Kognitívny deficit sme zist'ovali českými prekladmi testov Addenbrookský Kognitívny Test, Revidovaná Verzia, (ACE-R) a Mini-Mental State Examination (MMSE). Na screening depresie sme použili Škálu Geriatrickej Depresie v jej 15 položkovej českej verzii (GDS-15). Aktivity denného života sme posudzovali českými verziami Dotazníka Sebestačnosti (DAD-CZ) a Dotazníka Funkčného Stavu (FAQ-CZ). Reliabilitu sme overovali použitím Cronbachovej alfy. Použité metódy sa z psychometrického hl'adiska ukázali ako reliabilné nástroje.
\end{abstract}

Klíčová slova: demencia, vaskulárna demencia, Alzheimerova demencia, depresia, kognitívny deficit, aktivity denného života

\section{Úvod}

V rámci samostatne realizovaného výskumu k diplomovej práci, ktorá bola odovzdaná a obhájená 29.5.2012 na Psychologickom ústave FF Masarykovej univerzity, sme sa zamerali na problematiku diagnostiky demencie v praxi. Pôvodný zámer diplomovej práce bol nájst' vhodný algoritmus na rozlíšenie dvoch častých typov demencie Alzheimerovej (AD) a demencie vaskulárneho pôvodu (VD). Naším ciel’om bolo dokázat', že aj použitím jednoduchej batérie psychologických testov, ktorými je možno vyšetrit' pacienta v priebehu 45 minút, je možné zistit', či daný pacient trpí jednou či druhou formou demencie. Naše výsledky však boli z dôvodu viacerých metodologických nedostatkov pri určovaní objektívneho kritéria týchto typov diagnóz l'ahko spochybnitel'né - či sa jednalo o AD alebo VD sme rozhodovali čisto na podklade rôznorodých záznamov pacientov.

Na základe týchto záznamov však všetci vyšetrení pacienti mali lekárom stanovenú diagnózu demencie, a preto by sme sa chceli teraz, sodstupom dvoch rokov,

\footnotetext{
${ }^{1}$ Psychologický ústav, Filozofická fakulta MU, Arne Nováka 1, 60200 Brno
} 
k výsledkom vrátit' a aspoň čiastočne ich zhodnotnit' pre širšiu odbornú obec. Nami používané metódy sa totiž v priebehu práce ukázali ako vel'mi užitočné nástroje na diagnostiku a popis demencie. Nasledujúci článok si kladie za ciel' priblížit' tieto použité testy a popísat' ich psychometrické vlastnosti z pôvodných validizačných štúdií, ako aj z nášho vlastného výskumu.

Jirák popisuje demencie ako „závažní duševní poruchy, jejichž základními projevy jsou příznaky úbytku kognitivních (poznávacích) funkcí“ (Jirák in Höschl et al., 2004, p. 468). Zdôrazňuje pritom, že musí íst’ o úbytok funkcií, čo predpokladá, že daná funkcia musela byt' predtým prítomná a vistej miere rozvinutá. Ako hranica slúži orientačný vek 2-4 roky. Prítomnost' demencie vtak mladom veku je však našt'astie skôr výnimkou a demencie sú vo všeobecnosti syndrómom, ktorý sa týka staroby (Höschl et al., 2004).

Čistý úbytok kognitívnych funkcií, inak označovaný aj ako kognitívny deficit, je však na definíciu demencie v praxi málo. Podla WHO (2010) sa demencia prejavuje v niekol'kých základných oblastiach: postihnutí kognitívnych funkcií, čo zahŕňa najmä pamät', myslenie, orientáciu, chápanie, počítanie, schopnost' učenia, reči a úsudku; vedomie nebýva narušené; deteriorácii emočnej zložky; narušení sociálneho správania; defektoch v motivácii.

Jirák et al. (2009) kategorizuje poruchy pri demencii podobne na (1) poruchy kognitívnych funkcií, (2) poruchy aktivít denného života a (3) behaviorálne a psychologické príznaky demencie. Do poslednej kategórie zaradzuje okrem porúch emócií aj poruchy správania a spánku. Dodáva, že porušenie týchto funkcií musí byt' pre diagnózu demencie tak vel'ké, aby interferovalo s bežnými aktivitami života pacienta (Jirák et al., 2009).

Medzi d’alšie príznaky, ktoré začínajú v postihnutí emócií, patria pri demencii patické nálady, afektívna labilita, oploštelá afektivita či úbytok vyšších citov (Höschl et al., 2004). Tieto zmeny vedú k dopadu na správanie pacienta pri aktivitách všedného dňa, či dokonca k trvalej zmene osobnosti (Svoboda, Češková, \& Kučerová, 2006). V pokročilých štádiách demencie sa popisujú aj výrazné somatické problémy - telesná slabost', inkontinencia, zhoršenie imunity a poruchy pohybového aparátu (Kučerová, 2006).

Jedným z príznakov sprevádzajúcich kognitívny deficit u pacientov s demenciou sú problémy pri vykonávaní bežných činností, nazývaných aj aktivity denného života. Tieto schopnosti bývajú rozlišované na základné aktivity denného života (napr. príjem stravy a tekutín, hygiena) a inštrumentálne aktivity denného života (napr. nakupovanie, varenie a telefonovanie). K vyhodnoteniu týchto schopností bývajú najčastejšie používané posudzovacie škály, ktoré vyplní osoba poznajúca pacienta - ošetrovatel' či rodinný príslušník (Martínek \& Bartoš, 2010).

V zahraničí aj u nás je dostupná široká paleta týchto metód, ich aktuálny prehl'ad ponúkajú autori Martínek a Bartoš (2010). Vychádzajú z podobného zahraničného 
článku (Sikkes, Klerk, Pijnenburg, Scheltens, \& Uitdehaag, 2009), ktorý kriticky zhodnotil slabé psychometrické kvality väčšiny z nich.

\section{Metóda}

\section{Výskumný súbor}

Vhodnú vzorku populácie, kde by sa diagnóza demencie vyskytovala dostatočne často, sme sa rozhodli hl'adat' v Domove pro seniory Nopova v Brne.

Zamestnanci Domova pro seniory Nopova vyselektovali spomedzi svojich zverencov pacientov, ktorí mali demenciu l'ahkého, nanajvýš stredného stupňa. Rozhodovali tak na základe lekárom stanovenej diagnózy v záznamoch pacientov a priebežného vyšetrovania pacientov rozšírenou metódou Mini Mental State Examination (MMSE). Z tohto pôvodného zoznamu sme vylúčili pacientov, ktorí mali v zázname diagnostikovanú demenciu zmiešaného typu (teda v ich zázname bola aj vaskulárna, aj Alzheimerova demencia). Vylúčení boli aj pacienti s Parkinsonovou chorobou.

Po vyradení kandidátov z dôvodu úmrtia (od času pôvodného selektovania pacientov), zhoršenia stavu, odmietnutia spolupráce alebo chyby $\mathrm{v}$ dotazníkoch (zistenej po ukončení zberu údajov) sme dospeli k definitívnemu počtu 67 vyšetrených pacientov, $\mathrm{z}$ toho $52 \mathrm{~s}$ vaskulárnou a $15 \mathrm{~s}$ Alzheimerovou demenciou.

Z celého súboru boli šiesti pacienti muži, zvyšných 91\% tvorili ženy. Pacienti mali priemerný vek 82 rokov (SD =9) s extrémnymi hodnotami 100 rokov a 42 rokov. Vzdelanie sme mapovali v ordinálnych kategóriách „bez vzdelania“ (N = 1), „základné“ ( $\mathrm{N}=25)$, „stredoškolské bez maturity“ $(\mathrm{N}=24)$, „s maturitou“ $\quad(\mathrm{N}=12)$ a „vysokoškolské“ ( $\mathrm{N}=5)$.

\section{Procedúra}

Vybraní pacienti boli vyšetrení osobne testom kognitívnych funkcií Addenbrooke's Cognitive Examination - Revised (ACE-R, česká verzia Bartoš et al., 2011 z pôvodného testu od Mioshi et al., 2006). U 13 pacientov nebolo možné z dôvodu telesného postihnutia (slabý zrak, sluch či paréza horných končatín) vyhodnotit' všetky položky testu, zvyšní 54 pacienti mali test kompletný. Administrácia zabrala priemerne 15-25 minút. Test ACE-R v sebe obsahuje zahrnutý aj test MMSE.

Po tejto metóde nasledovalo vyšetrenie českou adaptáciou dotazníka na depresiu Geriatric Depresion Scale - GDS-15 (Yesavage \& Sheikh, 1986) trvajúce nanajvýš pät' minút. Z 67 pacientov nedokázala dokončit' tento test iba jedna pacientka, ktorá mala t’ažkú nedoslýchavost'.

Bez prítomnosti pacienta boli vyplnené posudzovacie škály Functional Activities Questionnaire (FAQ-CZ, český preklad od Bartoš et al., 2008 z pôvodného testu od 
Pfeffer et al., 1982) a Disability Assessment for Dementia (DAD-CZ, český preklad od Bartoš et al., 2009; pôvodná verzia testu od Gélinas \& Gauthier, 1994). Vyplnením škály boli poverené vždy osoby, ktoré mali dobrý prehl'ad o stave a schopnostiach pacienta, najčastejšie staničné sestry a ošetrovatelia. Pred vyplnením škály sme hodnotitel’om vždy krátko vysvetlili, ako sa s danou metódou pracuje, zdôraznili sme rozdiel medzi inštrukciami kvyplneniu oboch metód. Trinásti pacienti, u ktorých sme výsledky vyšetrenia prevzali zo záznamu, nemali vykonané posúdenie škálou DAD-CZ. Posúdenie škálou FAQ-CZ bolo vykonané u všetkých 67 pacientov.

Vyšetrovanie pacientov tak, ako bolo vykonané, sa približuje vyšetrovaniu v praxi tým, že metódy administrovali nielen školení psychológovia, ale aj ostatní odborne spôsobilí pracovníci pracujúci s pacientmi s demenciou. Všetky administrované metódy sú navrhnuté $v$ duchu použitel'nosti širokej odbornej obce, získané údaje preto zodpovedajú zámerom autorov metód ich využívania nielen psychológmi.

Všetky testy sú vol'ne dostupné. DAD-CZ, FAQ-CZ a ACE-R boli použité s vedomím autorov českého prekladu. Autorov prekladu GDS-15 sa nám nepodarilo vypátrat'.

\section{Popis jednotlivých metód a výsledky}

\section{MMSE a ACE-R}

Medzi najčastejšie používané metódy v diagnostike demencie patrí test Mini-Mental State Examination, MMSE (Folstein et al., 1975). Je to test, ktorým sa posudzuje prítomnost' a hĺbka kognitívneho deficitu pri demencii. Jeho výhodou je krátky rozsah, čo je u pomaly pracujúcich pacientov s demenciou nespornou výhodou. Ked’že administrácia testu zaberie len pár minút, používajú ho okrem psychológov aj neurológovia a psychiatri v ambulantnej praxi. Jeho rozsah je však značne limitujúci pre hlbšie posúdenie rozloženia kognitívneho deficitu, preto je odporúčaný len ako metóda orientačná a screeningová (Kučerová, 2006).

MMSE dosahuje pre diagnostiku demencie vysoké hodnoty senzitivity (80\%) a specificity (100\%), v kombinácii s kresbou hodín je možné senzitivitu zvýšit’ až na 90\% (Schramm et al., 2002). Ako cut-off hodnota je odporúčané skóre 24, prípadne 23 bodov (Cullen et al., 2005; Schramm et al., 2002).

Z MMSE vychádzali autori testu ACE - Addenbrooke's Cognitive Examination (Mathuranath, Nestor, Berrios, Rakowicz, \& Hodges, 2000), ktorý umožňuje presnejšie mapovanie involučných zmien v kognitívnych procesoch pri demencii a dokonca sa pokúša diferencovat' niektoré jej typy - frontotemporálnu demenciu (FTD) a Alzheimerovu demenciu (AD), vid' nižšie. ACE je metóda, ktorej administrácia zaberie znesitel'ných 12-20 minút a ponúka vo svojej revidovanej verzii (Mioshi, Dawson, Mitchell, Arnold, \& Hodges, 2006) kvalitné klinické parametre (senzitivita 84-94\%, specificita 89-100\%). Hranicou pre diagnózu demencie môže byt' hodnota 88/100 alebo 
82/100 bodov. Podl'a autorov je pri skóre 88 pravdepodobnost' demencie $8,4 \%$, pri skóre 82 je to už $100 \%$ (Mioshi et al., 2006).

Revízia testu ponúka možnost' posúdenia viacerých oblastí kognitívnych funkcií, ktorých narušenie je charakteristické pre demenciu - pozornost' a orientáciu (18 bodov), pamät' (26 bodov), slovnú produkciu (14 bodov), jazyk (26 bodov) a zrakovo-priestorové schopnosti (16 bodov). Súčast'ou testu je aj možnost' výpočtu indexu VLOM (V - skóre subtestu verbálna fluencia, $\mathrm{L}$ - subtest jazyk, $\mathrm{O}$ - subtest orientácia, $\mathrm{M}$ - subtest pamät'). Jednoduchý vzorec $(\mathrm{V}+\mathrm{L}) /(\mathrm{O}+\mathrm{M})$ by mal podl'a autorov umožnit' diferencovat' medzi $\mathrm{AD}$ a FTD. Podl'a predpokladu by mali pacienti s AD zlyhávat' najmä v subteste orientácie a pamäti - ich index VLOM by mal byt' preto vyšší ako 3,2. Pacienti s FTD by naopak mali dosahovat' zlý výsledok najmä v subteste verbálnej fluencie a jazyka, čím by ich index VLOM mal dosahovat' hodnoty nižšie ako 2,2 (Mioshi et al., 2006). Hodnoty hlavne senzitivity $(0,58$ pre FTD a 0,74 pre $\mathrm{AD})$ pre tento index sú však pomerne nízke (Mioshi et al., 2006).

Kvality testu sú overené vo viacerých nezávislých štúdiách. Ako užitočný sa ukázal aj v Austrálii, odporúčaná cut-off hodnota je tu však 84 bodov (Terpening, Cordato, Hepner, Lucas, \& Lindley, 2011). Autori na klinike v Liverpooli (Larner, 2007) zozbierali počas 3 a pol roka údaje od 285 pacientov. Podl'a ich výsledkov je ACE vhodný nástroj na diagnostikovanie demencie, navrhujú však využitie nižšej cut-off hodnoty (75 bodov) ako tvorcovia pôvodného testu. Pri tejto cut-off hodnote je podla Larnera (2007) senzitivita a specificita testu vyváženejšia ako pri pôvodnej. Pri 75 bodoch je senzitivita 0,85 a specificita 0,83 ; pri 83 sú hodnoty 0,96 a 0,63 a pri 88 bodoch 1,00 a 0,43 (Larner, 2007). Autori d'alej overovali schopnost' VLOM indexu v teste diferencovat' medzi diagnózou Alzheimerovej a frontotemporálnej demencie. Podl'a nich $v$ tomto test nedosiahol presvedčivé psychometrické hodnoty (najmä senzitivitu) a odporúčajú dopĺňat' diferenciálnu diagnostiku inými metódami (Larner, 2007).

ACE-R slúži dobre na diagnostiku demencie a mierneho kognitívneho deficitu aj pri Parkinsonovej chorobe (McColgan et al., 2012; Reyes et al., 2009). Okrem anglickej verzie sa ukazuje ako kvalitná aj napr. japonská (Yoshida et al., 2012) či talianska (Pigliautile et al., 2011) verzia testu.

Česká adaptácia revízie testu (Bartoš et al., 2011) ponúka používatel'sky príjemné prostredie vo formulári s presnými inštrukciami na administráciu a vyhodnotenie. Samostatný hárok je určený pre prácu pacienta.

\section{Výsledky}

Test v našom výskume dosiahol vysoké hodnoty vnútornej konzistencie. Cronbachova alfa pre 54 prípadov, v ktorých bol test úplne vyplnený (v ostatných boli niektoré časti vynechané, napr. kvôli zrakovému handikepu, vid' tabul'ka), dosiahla hodnotu 0,91. Odhad reliability týmto spôsobom je však zat'ažený vysokým počtom položiek, ktorých bolo spolu až 75 a vykazovali rôznorodú koreláciu s celkovým korigovaným skóre testu 
Štefan Anderko: Reliabilita batérie metód na vyhodnotenie kognitívneho deficitu, depresie a funkčného stavu pacientov s demenciou

(od 0,02 do 0,64; v jednom prípade ${ }^{2}$ dokonca položka korelovala negatívne -0,07). Lepší prehl'ad o psychometrickej kvalite testu preto ponúka analýza jeho subškál. Jej zhrnutie je v tabul'ke 1.

Tabul'ka 1 - nameraná reliabilita ACE-R a subškál

\begin{tabular}{|c|c|c|c|c|c|c|}
\hline & $\begin{array}{l}\text { body } \\
\text { spolu }\end{array}$ & $\begin{array}{c}\text { počet } \\
\text { položiek }\end{array}$ & $\begin{array}{l}\text { validné } \\
\text { prípady } \\
\text { (zo 67) }\end{array}$ & $\begin{array}{c}\text { Cronba- } \\
\text { chova } \\
\text { alfa }\end{array}$ & $\begin{array}{c}\text { korigovaná } \\
\text { korelácia položiek } \\
\text { s celkovým skóre } \\
\text { škály }\end{array}$ & $\begin{array}{c}\text { priemerná } \\
\text { medzipolož- } \\
\text { ková } \\
\text { korelácia }\end{array}$ \\
\hline $\begin{array}{l}\text { Pozornost } \\
\text { a orientace }\end{array}$ & 18 & 14 & 67 & 0,71 & $0,11-0,51$ & 0,21 \\
\hline Pamět' & 26 & $25(26)^{*}$ & 66 & 0,87 & $0,19-0,59$ & 0,22 \\
\hline $\begin{array}{l}\text { Slovní } \\
\text { produkce }\end{array}$ & 14 & 2 & 67 & 0,69 & 0,52 & 0,52 \\
\hline Jazyk & 26 & 23 & 54 & 0,81 & $0,09-0,61$ & 0,18 \\
\hline $\begin{array}{l}\text { Zrakově- } \\
\text { prostorové } \\
\text { schopnosti }\end{array}$ & 16 & 11 & 54 & 0,73 & $0,12-0,73$ & 0,21 \\
\hline ACE-R spolu & 100 & $75(76)^{*}$ & 54 & 0,91 & $0,02-0,64$ & 0,15 \\
\hline
\end{tabular}

* štatisticky boli spracované všetky položky okrem 17.6 - rozpamätania sa na obec Královice z adresy, čo sa prejavilo na chýbaní jednej položky v analýze subškály Pamět’ a tiež na analýze celého testu

Pozornost a orientace: Vynechanie položky „odečítaní čísla 7“ (úloha 3) by reliabilitu subškály mierne zvýšilo, a to na hodnotu 0,78. Jej vplyv na reliabilitu škály je pravdepodobne zvýraznený tým, že ide o položku, kde môže probant dosiahnut' skóre 0 až 5, kým vo všetkých ostatným položkách je to 0-1 bodov. Jej rozptyl (z ktorého je Cronbachova alfa počítaná) je teda vporovnaní s rozptylmi ostatných položiek niekol'konásobne vyšší.

Pamět: Obsahuje spolu 26 položiek, v našom prípade však došlo pri jednej položke knulovej variancii - žiaden z pacientov si na konci testu nedokázal vybavit' mesto Královice z naučenej adresy (úloha 17.6). Taktiež predchádzajúca položka, v ktorej sa pacient na konci testu rozpamätáva na popisné číslo vadrese (úloha 17.5) vykázala miernu odchýlku -korelovala s celkovým skóre len 0,19 . Vzhl'adom na náročnost' položky je však zníženie skóre pochopitel'né.

Slovní produkce: Pozostáva iba z dvoch úloh, a to vymenovania slov na zadané písmeno „p“ a vymenovania čo najviac zvierat, obe s časovým limitom jedna minúta. Cronbachova alfa síce dosiahla len 0,69; pre dve položky je to však nereprezentatívny údaj a vlastnosti subškály sú lepšie vyjadrené prostou koreláciou medzi položkami, ktorá dosiahla hodnotu 0,52.

\footnotetext{
${ }^{2}$ Išlo o prečítanie rozrušeného písmena „T“ (úloha 16.4).
} 
Jazyk: Položky korelovali s celkovým korigovaným skóre škály v rozsahu od 0,19 do 0,61 s výnimkou jedného prípadu (úloha 8b) - položka s úlohou, ked’ má pacient vziat' papier do pravej ruky, preložit' ho na polovicu a položit' na zem korelovala len 0,09 . Táto úloha je hodnotená maximálne troma bodmi, ostatné úlohy zväčša jedným bodom, len jedna d'alšia úloha (úloha 10a) bola hodnotená dvoma bodmi. Rozptyl výsledkov pre trojbodovú položku je preto väčší ako pre všetky ostatné a jej vylúčením by Cronbachova alfa mierne stúpla (na 0,83).

Zrakově-prostorové schopnosti: $\mathrm{V}$ tomto prípade došlo $\mathrm{k}$ opačnému fenoménu ako sme popisovali u subškál Jazyk a Pozornost a orientace. Bodovo najvyššie hodnotené položky, kreslenie hodín (úloha 14c) za 5 bodov a obkresl'ovanie kocky (úloha 14b) za 2 body boli nosnou čast’ou bodového rozptylu celej škály, preto korelovali s výsledkom celej škály obe tieto položky najviac $(0,73$ pre hodiny a 0,70 pre kocku). V subteste bolo najproblematickejšie čítanie písmena "T“ (úloha 16.4), ktoré korelovalo s celkovým skóre škály najmenej $(0,12)$ a jeho vynechaním z testu by vnútorná konzistencia mierne stúpla (na 0,74$)$

\section{FAQ}

Functional Activities Questionnaire (Pfeffer, Kurosaki, Harrah, Chance, \& Filos, 1982) je škála zameraná na staršiu populáciu všeobecne, či už s demenciou alebo bez nej. V pôvodnej validizačnej štúdii autori administrovali test dôchodcom, ktorí boli zdraví alebo mierne dementní. Validita škály bola overená koreláciou s ohodnotením reziduálnej funkčnosti pacienta neurológmi $(r=-0,83)$, ako aj so škálou Instrumental Activities of Daily Living - IADL (Lawton \& Brody, 1969; r = -0,68). Regresná analýza tiež odhalila, že pomocou FAQ možno vysvetlit’ značnú čast' rozptylu hodnôt popisujúcich funkčnost' pacienta (Pfeffer et al., 1982). Táto funkčnost' bola vypočítaná ako kombinácia výsledku v MMSE, subtestu Ravenových matíc a ohodnotení neurológov a sestier. Jednotlivé položky škály korelovali s celkovým výsledkom v rozsahu 0,8 až 0,9 (Pfeffer et al., 1982).

Česká verzia dotazníka, FAQ-CZ (Bartoš, Martínek, Bezdíček, Buček, \& Řípová, 2008), obsahuje desat' položiek, ktoré sú hodnotené na štyroch stupňoch hodnotených $0-3$ bodmi. Spolu tak možno dosiahnut' 0-30 bodov. Vyšší počet bodov vyjadruje v tomto teste väčšie postihnutie aktivít denného života (Bartoš et al., 2008).

\section{Výsledky}

V našom výskume bola škála úplne vyplnená pre všetkých 67 prípadov. Cronbachova alfa dosiahla hodnotu $\mathbf{0 , 8 8}$. Jednotlivé položky medzi sebou korelovali vysoko, priemerne 0,43 . Korelácie jednotlivých položiek s korigovaným celkovým skóre sa pohybovali v rozmedzí od 0,47 do 0,73 . Vynechanie ktorejkol'vek položky by hodnotu Cronbachovej alfy znížilo.

Extrémne vysoká korelácia medzi položkami bola v prípade prvej a druhej otázky, až 0,92. Ide o posúdenie schopnosti pacienta „Psát složenky nebo platit účty, ukladat si finanční doklady." a „Vyplňovat různe úřadní dokumenty nebo formuláře.“. Obe otázky 
sa pýtajú v podstate na ten istý jav, preto je pochopitel'né, že ho posudzovatelia označili $\mathrm{v}$ oboch prípadoch často podobne.

\section{DAD}

Disability Assessment for Dementia (Gélinas, Gauthier, McIntyre, \& Gauthier, 1999; Gélinas \& Gauthier, 1994) bol vyvinutý pôvodne pre pacientov s Alzheimerovou demenciou. Validita škály bola posúdená skupinou odborníkov, koreláciou so škálou Rapid Disability Rating Scale 2 (Linn \& Linn, 1982; r = -0,85) a koreláciou s výsledkom $\mathrm{v}$ teste MMSE $(\mathrm{r}=0,54)$. Cronbachova alfa pre test bola 0,96 , reliabilita metódou testretest 0,96 (Gélinas \& Gauthier, 1994).

V českom preklade (Bartoš, Martínek, Buček, \& Řípová, 2009) je zachovaný pôvodný spôsob administrácie metódy. Posudzovatel' sa vyjadruje ktomu, či pacient danú položku urobil bez pomoci a pripomenutia aspoň raz za posledné dva týždne odpoved'ami 1-ANO, 0-NE a X-NELZE URČIT. Položiek je spolu 40 a sú rozdelené do dvoch kategórií - základné aktivity denného života (17) a inštrumentálne aktivity denného života (23). V týchto základných kategóriách sú položky d’alej usporiadané do jednotlivých oblastí. Pre základné aktivity je to hygiena, obliekanie, kontinencia, jedenie; pre inštrumentálne aktivity sú to príprava jedla, telefonovanie, chodenie von a pobyt vonku, financie a korešpondencia, lieky, vol’ný čas a domáce práce. Jednotlivé položky sa navyše dajú zatriedit' do troch kategórií podl'a toho, do akej miery je daná činnost' zvládnutá. To môže byt' na úrovni iniciácie (napr. „Pokusil se obléknout“), plánovania a organizácie („Vybral/a si vhodné oblečení...") a správneho prevedenia úkonu („Oblékl/a se ve správném pořadí...”). Výstupom škály je percento vyjadrujúce mieru zachovanosti každodenných aktivít u pacienta (Bartoš et al., 2009).

\section{Výsledky}

V našom súbore bolo z analýzy reliability vylúčených až 5 položiek pre nulovú varianciu: položky 18-20 týkajúce sa prípravy jedla a položky 39 („Provedl/a domáce práce...") a 40 („... bylo ho/ji bezpečné nechat doma samotného/samotnou.“). Všetky tieto položky boli z druhej subškály (Instrumentální a volnočasové aktivity) a ich náplň je povinnost’ou pracovníkov domova pre seniorov. Pacienti ich preto z pohl'adu ich hodnotitel'ov bud' nepreviedli, alebo sa nedá posúdit', či by ich boli schopní previest'.

Zvyšných 35 položiek sme analyzovali pre 29 platných prípadov. Cronbachova alfa pri nich dosiahla hodnotu 0,92. Priemerná medzipoložková korelácia bola 0,27 . Položky korelovali s celkovým korigovaným skóre v širokom rozsahu od 0,01 do 0,77.

Subškála Základní aktivity obsahovala 17 položiek a bolo v nej platných 41 prípadov. Cronbachova alfa tu dosiahla 0,94. Priemerná medzipoložková korelácia bola 0,46 a jednotlivé položky korelovali s celkovým korigovaným skóre v rozmedzí 0,38 až 0,81 . Žiadna položka by svojím vylúčením nezvýšila reliabilitu subškály.

Subškála Instrumentální a volnočasové aktivity dosiahla pri 18 položkách a 30 platných prípadoch Cronbachovu alfu 0,88. Priemerná medzipoložková korelácia bola 
0,32 . S celkovým korigovaným skóre korelovali položky v rozsahu 0,24 až 0,75 . Podobne ako v prípade predchádzajúcej subškály, reliabilitu by sme nezvýšili vylúčením žiadnej z položiek.

\section{GDS}

$\mathrm{Na}$ zachytenie depresie vstaršom veku možno použit' všeobecné dotazníky či posudzovacie škály, vhodnejšie je však siahnut’ po špecializovaných metódach. Jednou z nich je dotazník Geriatric Depression Scale, GDS (Yesavage et al., 1983). Dotazník existuje vo viacerých formách. Pôvodná obsahovala 30 otázok. Neskôr bola upravená na verziu s 15 otázkami (Yesavage \& Sheikh, 1986).

Pri porovnaní s diagnostikovaním depresie podl'a DSM-IV dosiahol skrátený test GDS-15 pri svojej cut-off hodnote 5 bodov senzitivitu 72\% a specificitu 78\% u pacientov prijímaných do domova dôchodcov (Marc, Raue, \& Bruce, 2008). Spomedzi viacerých verzií dotazníka je práve 15 položková GDS-15 považovaná za najvhodnejší nástroj pre screening depresie v špecializovaných domovoch pre seniorov (Mitchell, Bird, Rizzo, \& Meader, 2010).

V češtine existuje viacero prekladov tohto dotazníka ${ }^{3}$. Dotazník GDS-15 obsahuje 15 položiek, ktoré sú všetky bodované rovnako, a to 0 alebo 1 . Pacientova nálada je vyhodnotená ako „normální nálada bez deprese“ ak dosiahne 0-5 bodov, „mírna deprese“ pri 6-10 bodoch a „manifestní deprese vyžadující podrobné vyšetření“ pri výsledku nad 10 bodov.

\section{Výsledky}

V našom výskume bol test validný pre 66 zo 67 prípadov (jedna pacientka ho z dôvodu vel'kej citlivosti na otázky nedokázala dokončit'). Cronbachova alfa dosiahla hodnotu 0,81. Priemerná korelácia medzi položkami mala hodnotu 0,22 . Desat’ položiek koreluje s celkovým korigovaným skóre testu v rozsahu 0,3-0,65.

Štyri položky korelujú nižšie. Pri otázke „Vzdal(a) jste se v poslední době mnoha činností a zájmů?“ je korelácia len 0,13 . Táto položka nemusí u pacientov, ktorí ju zodpovedajú kladne (a dostanú 1 bod) nutne znamenat' príznak depresie - s rastúcou invaliditou a obmedzením aktivít $\mathrm{z}$ dôvodu ich nedostupnosti vdomove pre seniorov je to u mnohých prostý fakt.

Podobne je natom položka „Myslíte si, že máte větší potíže s pamětí než vaši vrstevníci?", ktorá koreluje s celkovým skóre 0,21. Môžeme predpokladat', že mnohí pacienti odpovedali na túto otázku vecne, zmierení s prirodzeným priebehom svojej choroby. Táto otázka je zároveň jedinou otázkou dotazníka, ktorej vylúčenie by mierne zvýšilo Cronbachovu alfu (na 0,82).

\footnotetext{
${ }^{3}$ Vychádzame z prekladu „Škála deprese pro geriatrické pacienty“ v materiáloch od firmy Pfizer, vid” príloha II. Bližšie údaje o preklade dotazníka v tejto verzii sa nám nepodarilo nájst'.
} 
V otázke „Obávate se, že se vám přihodí něco zlého?“ bola korelácia s celkovým skóre 0,24 . Aj táto otázka môže reprezentovat' skutočnú, opodstatnenú obavu napr. z d'alšej mozgovej príhody, alebo naopak, pri negatívnej odpovedi odovzdanost' situácii (pacient môže odpovedat', že sa neobáva s tým, že už to horšie byt' nemôže - za položku dostáva 0 bodov, avšak charakter jeho "NE“ vypovedá skôr o depresivite a teda 1 bode).

Otázka „Nudíte se často?“ dosiahla koreláciu s celkovým skóre 0,29 . V tomto prípade sme pri dodatočnej analýze odpovedí zistili, že $75 \%$ pacientov odpovedalo „NE“, čo je najuäčší nepomer v rozložení odpovedí na otázky GDS-15. To by mohlo znamenat', že náplň aktivít domova pre seniorov zamestnáva plne väčšinu jeho obyvatel'ov a ani tí depresívnejší proste nevnímajú svoj čas ako strávený nudou.

Položka „Máte většinou dobrou náladu?“ naopak korelovala s celkovým výsledkom najvyššie, až 0,70 . V tomto prípade je zrejmé, že daná položka sa v podstate pýta na to, o čo sa snaží celý dotazník, a to na prevažujúcu prítomnost' dobrej nálady alebo tej zlej depresie.

Môžeme uzavriet', že GDS-15 je vnútorne konzistentný dotazník s Cronbachovou alfou 0,81, v ktorom je ale pri tejto vzorke otázna najmä položka pýtajúca sa na problémy s pamät'ou, ktoré všetci naši vyšetrení pacienti objektívne majú, a teda nie je isté, do akej miery odpoved' na ňu vyjadruje skepsu alebo náhl'ad na svoj stav.

\section{Diskusia}

\section{Rozbor výsledkov}

Prítomnost' kognitívneho deficitu je univerzálnou podmienkou diagnostikovania demencie (American Psychiatric Association, 2000; Höschl et al., 2004; Koukolík \& Jirák, 1999; WHO, 2010 a mnohí d'alší). Jeho nájdenie u pacientov s už diagnostikovanou demenciou je preto $\mathrm{v}$ podstate potvrdením splnenia jedného $\mathrm{z}$ predpokladov pri diagnostickom procese, resp. dôkaz o nezmenenom stave pacienta od vyslovenia diagnózy.

Prítomnost' tohto deficitu meraného kognitívnymi testami na druhej strane nevypovedá jednoznačne o prítomnosti demencie u pacienta. Hlavne pri pacientoch $\mathrm{s}$ vyšším výkonom v teste ACE-R, t. j. tých, ktorí dosiahli viac ako 82 bodov je pravdepodobnost' prítomnosti demencie trochu nižšia. Pre pacientku, ktorá dosiahla najvyšší počet bodov (86) v našom súbore je táto pravdepodobnost' podl'a autorov testu 14,2\% (Mioshi et al., 2006). Demencia sa $\mathrm{v}$ podobných prípadoch t’ažko ohraničuje a neostré prechody v spektre demencia, mierny kognitívny deficit a normálne starnutie môžu byt' chápané rozličnými odborníkmi odlišne.

V diagnostickom procese je potom nápomocné orientačné vyšetrenie škálami zameranými na zhodnotenie schopnosti aktivít denného života. Súčast'ou definícií demencie je totiž aj to, že narušenie kognitívnych (a d'alších) schopností musí byt' 
prejavené aj v pacientovom bežnom živote (Jirák et al., 2009). Dokáže sa pacient postarat' sám o seba tak ako predtým? Túto otázku aplikovanú na rozličné oblasti každodenného života, ktoré samostatný človek musí zvládat' v podstate automaticky, kladú $\mathrm{v}$ obmenách posudzovacie škály osobe $\mathrm{z}$ blízkosti pacienta. Pri splnení predpokladu, že posudzujúca osoba má reálny prehl'ad o schopnostiach pacienta tak môže výstup z tejto škály relevantne prispiet’ k diagnostickému rozhodovaniu. $\mathrm{V}$ prípade vyššie spomínanej pani s pomerne vysokým výkonom v kognitívnom teste si napríklad môžeme všimnút', že jej percentuálne vyjadrené zachovanie aktivít denného života pomocou DAD-CZ je len 75\% a v škále FAQ-CZ dosiahla iba 9 bodov z 30.

V našom výskume sme pôvodne predpokladali, že u všetkých pacientov s diagnózou demencie bude nájdené zhoršenie v schopnosti vykonávat' aktivity denného života, resp. ich posudok nebude stopercentný či dosahovat’ plný počet bodov. Vychádzali sme najmä z očakávanej zníženej samostatnosti pacientov v domove pre seniorov. Medzi pacientmi domova sa ale paradoxne našlo viacero jednotlivcov, ktorých posúdenia $\mathrm{v}$ škálach dosahovali vel'mi dobré výsledky, jedna pani dokonca skórovala 0 bodov v škále FAQ-CZ a 100\% v DAD-CZ zároveň. Išlo o pani, ktorá mala problémy so zrakom a preto jej presný výsledok v kognitívnom teste nebol dostupný, na základe parciálneho výsledku sme však vyrátali, že v teste ACE-R by mohla dosiahnut' výsledky v rozmedzí 34-69 bodov a v teste MMSE 19-24 bodov. Na základe toho môžeme vidiet', že u nej kognitívny deficit je prítomný, napriek tomu sú schopnosti aktivít denného života podl’a posudzovacích škál úplne zachované.

Tento výsledok je v súlade s údajmi získanými pri pôvodnej validizačnej štúdii DAD, kde sa taktiež nachádzalo 100\% zachovanie schopností aktivít denného života u pacienta s demenciou (Gélinas et al., 1999). Aj pri českej adaptácii škály našli autori prekladu prípady s vysokým, až 97 percentným, zachovaním schopností aktivít denného života (Bartoš et al., 2009). Z pôvodnej štúdie k FAQ (Pfeffer et al., 1982) síce nemožno vyčítat' výkony pacientov s demenciou a ich rozloženie, $v$ českom preklade je však z rozloženia výsledkov jasné, že aj tu dosiahli pacienti s demenciou vyše 90 \% zachovanie schopností aktivít denného života (Bartoš et al., 2008).

Krátky dotazník GDS-15 je metóda, ktorou sme vyhodnocovali prítomnost' depresie, presnejšie povedané, depresívnych príznakov u pacientov. Treba zdôraznit', že sa nejednalo o definitívnu a presnú diagnózu depresie, ale skôr o orientačné vyšetrenie upozorňujúce na tendencie pacientov $\mathrm{k}$ depresivite.

\section{Nedostatky výskumu}

Jednou zo slabín predkladanej práce je zloženie výskumného súboru. V súbore boli ženy zastúpené s prevahou až 91\%. Tento fakt môže súvisiet' s tým, že ženy sa dožívajú vyššieho veku a zároveň je u nich častejší výskyt demencie. Predpokladat' môžeme aj vysvetlenie tým, že ženy sú do domovov dôchodcov umiestňované častejšie. K tomu dochádza kvôli väčšej potrebe starostlivosti o zdravie zo strany žien (Cameron, Song, Manheim, \& Dunlop, 2010). V našom prípade sme pre kontrolu porovnali mužov a ženy 
Mann-Whitneyho U testom, ktorý nezistil signifikantné rozdiely medzi skupinami $\mathrm{v}$ žiadnom z výsledkov porovnávaných $\mathrm{v}$ d'alších analýzach.

Diagnostický proces pre tento výskum nebol štandardizovaný, vyberali sme pacientov podl'a označenia z ich anamnézy. Diagnózy zadávali rôzni lekári (neurológovia, psychiatri, všeobecní lekári) a je nepravdepodobné, že by sa všetci riadili tými istými kritériami pri vynesení diagnózy. Tento fakt bol limitujúci hlavne v pôvodnom zámere štúdie (rozlíšit' skupiny s Alzheimerovou a vaskulárnou demenciou). Spolu s orientačným výsledkom v teste MMSE však tieto záznamy poskytli dostatočný podklad pre zamestnancov domova pro seniory na vyselektovanie pacientov, ktorí s vysokou pravdepodobnost'ou demenciu mali.

Zber údajov psychodiagnostickými metódami je d'alším bodom, v ktorom mohlo dôjst' $\mathrm{k}$ viacerým intervenujúcim činitel’om. Údaje boli zbierané v rámci možností domova pre seniorov. V ideálnom prípade boli metódy administrované pacientom v oddelenej, tichej a dostatočne osvetlenej miestnosti - malom salóniku za schodišt’om. Imobilných pacientov sme však museli vyšetrit' priamo na lôžku, často $\mathrm{v}$ prítomnosti ich spolubývajúcich. Niektorí pacienti boli vyšetrovaní po návrate z hospitalizácie, iní po prekonaní bežného infekčného ochorenia - toto sa taktiež mohlo prejavit' na zvýšenej unavitel'nosti a horšom výkone v kognitívnom teste, prípadne skreslení v dotazníku na depresiu.

Aj motivácia jednotlivých pacientov k spolupráci bola rôzna. Jedni sa snažili podat’ čo najlepší výkon, doslova predviest' sa. Iní odpovedali len v rozsahu povinnosti. Našli sa aj takí, ktorí sa po začatí testu začali vyhovárat’ a chceli ho predčasne ukončit'. Ak odolali aj našej opakovanej prosbe o spoluprácu, toto ukončenie im bolo, samozrejme, umožnené.

Samotná administrácia bola prevádzaná viacerými osobami. Napriek našej snahe zabezpečit' aby všetci administrovali testy štandardizovaným postupom mohlo dôjst' do istej miery $\mathrm{k}$ skresleniu výsledku administrátorom. Porovnanie jednotlivých administrátorov, ktorých počet dosiahol 15 a niektorí z nich vyšetrili len jedného pacienta, by pri vel'kosti súboru nebolo zmysluplné. Ide tak o d'alšiu slabinu práce, na ktorú musíme pri interpretácii výsledkov mysliet'. Zároveň však zdôrazňujeme fakt, že administrované metódy boli navrhované s ciel'om širokej použitel'nosti v praxi, čomu sa nám týmto spôsobom vyšetrovania podarilo priblížit'.

\section{Záver}

Z hladiska psychometrických vlastností, hlavne vnútornej konzistencie testov, hodnotíme metódy popísané vyššie ako kvalitné nástroja, ktoré môžu demenciu u pacientov nielen diagnostikovat', ale vo svojej kombinácií aj dobre popísat'. Využitie viacerých metód, ktoré okrem zamerania na kognitívny deficit (ACE-R, MMSE) mapujú aj d'alšie dotknuté oblasti stavu pacientov (funkčný stav - DAD-CZ FAQ-CZ; depresia GDS-15), umožňuje hlbší popis stavu pacienta. 
Môžeme tak určit’ nielen to, či pacient spĺňa diagnostické kritéria demencie, ale aj to, do akej miery je schopný samostatne fungovat’ v reálnom živote. Jednotlivé položky jednej či druhej použitej posudzovacej škály funkčného stavu môžu vklinickej praxi nasmerovat’ ošetrujúci personál na oblasti, v ktorých má pacient nedostatky a potrebuje pomoc.

K tomu sa pridáva významný faktor orientačného zhodnotenia emočného stavu pacienta pomocou krátkeho dotazníka GDS-15. Depresia, či už spôsobená zhoršením kognitívneho stavu, alebo ako komorbidita, môže bezpochyby výrazne znížit' kvalitu života pacientov. Jej zachytenie, odlíšenie od prejavov kognitívnej deteriorácie a následná terapia je preto vel'kým príspevkom k celkovej liečbe pacienta.

Na použitých metódach oceňujeme okrem ich psychometrických kvalít aj ich používatel'sky príjemné spracovania. Metódy sú vo svojich českých verziách, za ktorými stojí mnoho práce doc. Bartoša a jeho tímu z AD Centra Praha, graficky prehl'adne spracované, obsahujú jasné inštrukcie na zadávanie položiek aj ich vyhodnocovanie a sú dostupné zdarma pre širokú odbornú obec. Pracovat’ s nimi môže po krátkom zaškolení ktorýkol'vek zdravotnícky pracovník.

Posudzovacie škály využívajú cenný objektívny pohl'ad na pacienta zo strany blízkej osoby. V kombinácií so subjektívnym hodnotením pacienta samého, ktoré poskytuje v dotazníku na depresiu, a výkonnostným hodnotením pomocou kognitívneho testu tak získavame informácie z viacerých zdrojov.

Jednoduchost', prístupnost' a vysoká klinická hodnota získaných údajov robí z týchto metód nástroje, ktoré môžu v praxi poslúžit' ošetrujúcemu personálu a zároveň nezat’ažit' pacienta náročným a zdíhavým vyšetrením.

\section{Zdroje}

American Psychiatric Association. (2000). Diagnostic and Statistical Manual of Mental Disorders, Fourth Edition, Text Revision (4 ed.). Washington, DC: American Psychiatric Association.

Bartoš, A., Raisová, M., \& Kopeček, M. (2011). Amendment of the Czech Addenbrooke's Cognitive Examination (ACE-CZ). Česká a slovenská Neurologie a Neurochirurgie, 74(6), 681-684.

Bartoš, A., Martínek, P., Bezdíček, O., Buček, A., \& Řípová, D. (2008). Dotazník funkčního stavu FAQ-CZ - česká verze pro zhodnocení každodenních aktivit pacientů s alzheimerovou nemocí. Psychiatrie pro Praxi, 9(1), 31-34.

Bartoš, A., Martínek, P., Buček, A., \& Řípová, D. (2009). Dotazník soběstačnosti DAD-CZ - česká verze pro hodnocení každodenních aktivit pacientů s Alzheimerovou nemocí. Neurologie pro praxi, 10(5), 320-323.

Cameron, K. A., Song, J., Manheim, L. M., \& Dunlop, D. D. (2010). Gender Disparities in Health and Healthcare Use Among Older Adults. Journal of Womens Health, 19(9), 1643-1650.

Cullen, B., Fahy, S., Cunningham, C. J., Coen, R. F., Bruce, I., Greene, E., ... Lawlor, B. A. (2005). Screening for dementia in an Irish community sample using MMSE: a comparison of norm- 
Štefan Anderko: Reliabilita batérie metód na vyhodnotenie kognitívneho deficitu, depresie a funkčného stavu pacientov s demenciou

adjusted versus fixed cut-points. International Journal of Geriatric Psychiatry, 20(4), 371376.

Folstein, M. F., Folstein, S. E., \& McHugh, P. R. (1975). "Mini-mental state”: a practical method for grading the cognitive state of patients for the clinician. Journal of Psychiatric Research, 12(3), 189-198.

Gélinas, I., \& Gauthier, L. (1994). Disability Assessment for Dementia (DAD), User's Guide. Retrieved 24.4., 2012, from http://www.dementia-assessment.com.au/function/DAD_manual.pdf

Gélinas, I., Gauthier, L., McIntyre, M., \& Gauthier, S. (1999). Development of a functional measure for persons with Alzheimer's disease: The disability assessment for dementia. American Journal of Occupational Therapy, 53(5), 471-481.

Höschl, C., Libiger, J., \& Švestka, J. (2004). Psychiatrie. Praha: Tigis.

Jirák, R., Holmerová, I., Borzová, C., Franková, V., Kalvach, Z., Konrád, J., . . Jarolímová, E. (2009). Demence a jiné poruchy paměti (1. ed.). Praha: GRADA publishing.

Koukolík, F., \& Jirák, R. (1999). Diagnostika a léčení syndromu demence. Praha: GRADA Publishing.

Kučerová, H. (2006). Demence v kazuistikách (1. ed.). Praha: GRADA publishing.

Larner, A. J. (2007). Addenbrooke's Cognitive Examination (ACE) for the diagnosis and differential diagnosis of dementia. Clinical Neurology and Neurosurgery, 109(6), 491-494.

Lawton, M. P., \& Brody, E. M. (1969). Assessment of older people - self-maintaining and instrumental activities of daily living. Gerontologist, 9(3P1), 179-\&.

Linn, M. W., \& Linn, B. S. (1982). The rapid disability rating-scale .2. Journal of the American Geriatrics Society, 30(6), 378-382.

Marc, L. G., Raue, P. J., \& Bruce, M. L. (2008). Screening Performance of the 15-Item Geriatric Depression Scale in a Diverse Elderly Home Care Population. American Journal of Geriatric Psychiatry, 16(11), 914-921.

Martínek, P., \& Bartoš, A. (2010). Dotazníky k hodnocení běžných činností u pacientů s Alzheimerovou nemocí. Psychiatrie, 14(4), 175-180.

Mathuranath, P. S., Nestor, P. J., Berrios, G. E., Rakowicz, W., \& Hodges, J. R. (2000). a brief cognitive test battery to differentiate Alzheimer's disease and frontotemporal dementia. Neurology, 55(11), 1613-1620.

McColgan, P., Evans, J., Breen, D. P., Mason, S. L., Ghosh, B., Rittman, T., ... Williams-Gray, C. H. (2012). The utility of the Addenbrooke's cognitive examination-revised (ACE-R) in parkinson's disease. Journal of Neurology Neurosurgery and Psychiatry, 83(3).

Mioshi, E., Dawson, K., Mitchell, J., Arnold, R., \& Hodges, J. R. (2006). The Addenbrooke's Cognitive Examination Revised (ACE-R): a brief cognitive test battery for dementia screening. [Article]. International Journal of Geriatric Psychiatry, 21(11), 1078-1085.

Mitchell, A. J., Bird, V., Rizzo, M., \& Meader, N. (2010). Which Version of the Geriatric Depression Scale is Most Useful in Medical Settings and Nursing Homes? Diagnostic Validity MetaAnalysis. American Journal of Geriatric Psychiatry, 18(12), 1066-1077. 
Štefan Anderko: Reliabilita batérie metód na vyhodnotenie kognitívneho deficitu, depresie a funkčného stavu pacientov s demenciou

Pfeffer, R. I., Kurosaki, T. T., Harrah, C. H., Chance, J. M., \& Filos, S. (1982). Measurement of functional activities in older adults in the community. Journals of Gerontology, 37(3), 323329.

Pigliautile, M., Ricci, M., Mioshi, E., Ercolani, S., Mangialasche, F., Monastero, R., . . Mecocci, P. (2011). Validation Study of the Italian Addenbrooke's Cognitive Examination Revised in a Young-Old and Old-Old Population. Dementia and Geriatric Cognitive Disorders, 32(5), 301-307.

Reyes, M. A., Lloret, S. P., Gerscovich, E. R., Martin, M. E., Leiguarda, R., \& Merello, M. (2009). Addenbrooke's Cognitive Examination validation in Parkinson's disease. [Article]. European Journal of Neurology, 16(1), 142-147.

Schramm, U., Berger, G., Muller, R., Kratzsch, T., Peters, J., \& Frolich, L. (2002). Psychometric properties of Clock Drawing Test and MMSE or Short Performance Test (SKT) in dementia screening in a memory clinic population. International Journal of Geriatric Psychiatry, 17(3), 254-260.

Sikkes, S. A. M., Klerk, E., Pijnenburg, Y. A. L., Scheltens, P., \& Uitdehaag, B. M. J. (2009). a systematic review of Instrumental Activities of Daily Living scales in dementia: room for improvement. Journal of Neurology Neurosurgery and Psychiatry, 80(1), 7-12.

Svoboda, M., Češková, E., \& Kučerová, H. (2006). Psychopatologie a psychiatrie. Praha: Portál.

Terpening, Z., Cordato, N. J., Hepner, I. J., Lucas, S. K., \& Lindley, R. I. (2011). Utility of the Addenbrooke's Cognitive Examination - Revised for the diagnosis of dementia syndromes. Australasian Journal on Ageing, 30(3), 113-118.

WHO. (2010). International Statistical Classification of Diseases and Related Health Problems, 10th Revision - ICD 10 10. Retrieved 27.1., 2012, from http://apps.who.int/classifications/icd10/browse/2010/en ; slovensky: http://www.nczisk.sk/Standardy-v-zdravotnictve/Pages/Medzinarodna-klasifikaciachorob-MKCH-10.aspx ; http://data.nczisk.sk/old/infozz/mkch/mkch-10/cast0500.pdf

Yesavage, J. A., Brink, T. L., Rose, T. L., Lum, O., Huang, V., Adey, M., \& Leirer, V. O. (1983). Development and validation of a geriatric depression screening scale - a preliminary-report. Journal of Psychiatric Research, 17(1), 37-49.

Yesavage, J. A., \& Sheikh, J. I. (1986). Geriatric Depression Scale (GDS): Recent evidence and development of a shorter version. Clinical Gerontologist, 5(1-2), 165-173.

Yoshida, H., Terada, S., Honda, H., Kishimoto, Y., Takeda, N., Oshima, E., ... Uchitomi, Y. (2012). Validation of the revised Addenbrooke's Cognitive Examination (ACE-R) for detecting mild cognitive impairment and dementia in a Japanese population. International Psychogeriatrics, 24(1), 28-37. 


\section{Anderko, Š. (2015): Reliability of tests for the assessment of cognitive deficit, depression and functional status of patients with dementia.}

Abstract: In clinical research we have administered various psychodiagnostic methods to a sample of patients $(\mathrm{N}=67)$ of Domov pro seniory Nopova (retirement home) with the objective to verify their reliability in context of broader description of dementia. The cognitive deficit was measured using the Czech translations of Addenbrooke's Cognitive Examination-Revised (ACE-R) and Mini-Mental State Examination (MMSE). For the screening of the depression we used the Geriatric Depression Scale in its 15-item Czech version (GDS-15). The activities of daily living were assessed using the Czech versions of Disability Assessment for Dementia (DAD-CZ) and Functional Activities Questionnaire (FAQ-CZ). The reliability was verified with Cronbach's alpha. The used methods proved to be reliable tools in psychometric terms.

Keywords: dementia, vascular dementia, Alzheimer's dementia, depression, cognitive impairment, activities of daily living

Podpořeno z projektu OPVK:

SOVA-21 - Internacionalizace, inovace, praxe: sociálně-vědní vzdělávání pro 21. století,

CZ.1.07/2.2.00/28.0225
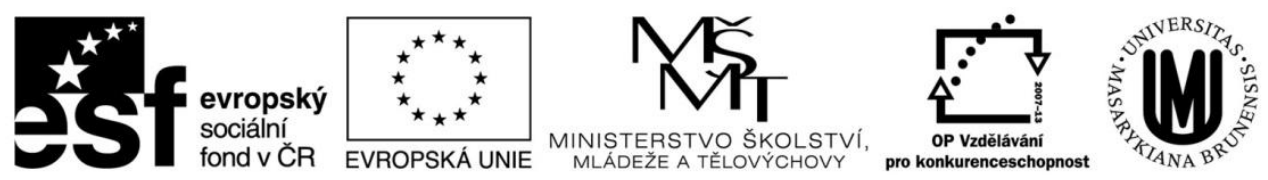

INVESTICE DO ROZVOJE VZDĚLÁVÁNÍ 